\title{
Penataan Artistik Pertunjukan Teater Dul Muluk Tunas Harapan di Palembang
}

\author{
Dedy Firmansyah $^{1)}$, Nugroho Notosutanto Arhon Dhony ${ }^{2)}$ \\ ${ }^{122) 31}$ Pendidikan Seni Pertunjukan, FKIP Universitas PGRI Palembang \\ JL. Ahmad Yani Lorong Gotong Royong 9/10 Ulu Palembang \\ Email : firmansyahdedy321@gmail.com ${ }^{1)}$, arhondhony13@ gmail.com ${ }^{2)}$
}

\begin{abstract}
Artistic arrangement is important in theater performances, as is Dul Muluk theater. "Decoration (scenery) is a background scene (background) where to play the play". Dul Muluk Theater is inseparable from the elements that support the show. The elements are divided into two parts, namely the main elements and supporting elements of the show. The main elements consist of: director, script, performer (actor / actress) and audience, while supporting elements of the show include: dress, property set, musical system, and stage decoration / decoration set. But in discussing this research journal, the writer discusses the supporting elements of his performance. The object of study in the research journal was the traditional arts group Dul Muluk Tunas Harapan, Pemulutan District, which was staged in Palembang. The theory used in this research journal is through Dramaturgi Harymawan's approach as grand theory. This type of research used in this research journal uses descriptive qualitative analysis. Data collection techniques carried out by observation, literature study, interviews, and documentation. The results of the research include; 1) Clothing that is useful to reinforce the character in accordance with the needs of the play, 2) Property as supporting elements of equipment in a theater performance, 3) Music Arrangement; apart from being a accompanist, illustrations, both as opening all the plays, opening scenes, giving effect to the play, and as a closing act also to give color and impression to the scene depicted on stage, 4) Tata Performances; the atmosphere of a place where the human soul can fly freely. A place where art is given breath.
\end{abstract}

Keywords : Artistic Settings, Dul Muluk Theater, and Dramaturgy Theory

\begin{abstract}
Abstrak
Penataan artistik merupakan hal yang penting dalam pertunjukan teater, seperti halnya teater Dul Muluk. "Dekorasi (scenery) merupakan pemandangan latar belakang (background) tempat memainkan lakon". Teater Dul Muluk tidak terlepas dari unsur-unsur yang mendukung pertunjukan. Unsur-unsur tersebut dibagi menjadi dua bagian, yaitu unsur pokok dan unsur pendukung pertunjukan. Unsur pokok terdiri dari: sutradara, naskah, pemain (aktor/aktris) dan penonton, sedangkan unsur pendukung pertunjukan meliputi: tata pakaian, set properti, tata musik, dan tata pentas/set dekorasi. Namun dalam pembahasan jurnal penelitian ini penulis membahas unsur pendukung pertunjukannya. Obyek yang dijadikan kajian dalam jurnal penelitian adalah kelompok seni tradisional teater Dul Muluk Tunas Harapan Kecamatan Pemulutan yang dipentaskan di Palembang. Teori yang digunakan dalam jurnal penelitiaan ini yaitu melalui pendekatan Dramaturgi Harymawan sebagai grand teori. Jenis penelitian yang digunakan dalam jurnal penelitian ini menggunakan analisis deskriptif kualitatif. Tehnik pengumpulan data dilakukan dengan cara observasi, studi pustaka, wawancara, dan dokumentasi. Adapun hasil penelitian di antaranya adalah; 1) Tata Pakaian yang berguna untuk mempertegas karakter sesuai dengan keperluan lakon, 2) Properti sebagai unsur pendukung perlengkapan dalam pertunjukan teater, 3) Tata Musik; selain sebagai pengiring, ilustrasi, baik sebagai pembuka seluruh lakon, pembuka adegan, memberi efek pada lakon, maupun sebagai penutup lakon juga untuk memberi warna dan kesan pada adegan yang digambarkan di atas pentas, 4) Tata Pentas; suasana tempat di mana jiwa manusia dapat terbang dengan bebas. Suatu tempat di mana seni diberi nafas.
\end{abstract}

Kata kunci : Peanataan Artistik, Teater Dul Muluk, dan Teori Dramaturgi 


\section{Pendahuluan}

Kesenian tradisional Palembang yang memiliki corak dan ragam dengan berbagai variasinya, merupakan warisan budaya bangsa yang tak ternilai harganya oleh karena itu perlu dilestarikan. Bandem dan Murgiyanto mengemukakan "teater tradisi adalah teater daerah yang telah hidup, berkembang, dan diajarkan secara turuntemurun dari generasi ke-generasi, biasanya secara lisan" (1996:17). Teater Dul Muluk yang hidup dan berkembang di Palembang dari tradisi pembacaan syair dihadapan para pendengarnya dalam bentuk Teater Tutur atau Teater Mula, yaitu kisah petualangan Abdul Muluk yang diceritakan oleh Wan Bakar seorang pedagang keturunan Arab.

Lama kelamaan pembacaan kisah tersebut disertai peragaan, oleh beberapa orang ditambah musik sebagai pengiring lalu dipentaskan dalam bentuk pertunjukan di atas pentas. Kisah yang diangkat dalam pertunjukan teater Dul Muluk yang dipentaskan oleh kelompok seni Tunas Harapan Kecamatan Pemulutan, yaitu Kisah Kejayaan Kerajaan Melayu dalam Syair Abdul Muluk Jauhari.

Kelompok seni Tunas Harapan merupakan kelompok seni yang berasal dari Kecamatan Pemulutan. Dengan bidang seni Teater Tradisional, biasanya membawakan pertunjukan Teater Bangsawan dan Teater Dulmuluk. Dalam pertunjukannya yang digelar oleh Dinas Kebudayaan Kota Palembang di Panggung Belakang Museum. Membawakan Teater Dul Muluk berjudul Kisah Abdul Muluk Jauhari dengan karakteristik dan gaya tersendiri.

"Teater merupakan "gedung pertunjukan" ada yang mengartikanya sebagai 'panggung" (stage). Dalam arti luas teater merupakan segala tontonan yang dipertunjukan di depan orang banyak. Dalam arti sempit, drama ialah kisah hidup manusia yang diceritakan di atas pentas, disaksikan oleh orang banyak, dengan media, percakapan, gerak dan laku, dengan atau tanpa dekor (layar dan sebagainya), didasarkan pada naskah yang tertulis (hasil seni sastra) dengan atau tanpa musik, nyanyian, tarian" (Harymawan, 1993:2).

Penataan artistik merupakan hal yang penting dalam pertunjukan teater seperti halnya teater Dul Muluk. "Dekorasi (scenery) merupakan pemandangan latar belakang (background) tempat memainkan lakon" (Harymawan, 1993:108). Teater Dul Muluk tidak terlepas dari unsur-unsur yang mendukung pertunjukan. Unsur-unsur tersebut dibagi menjadi dua bagian, yaitu unsur pokok dan unsur pendukung pertunjukan. Unsur pokok terdiri dari: sutradara, naskah, pemain (aktor/aktris) dan penonton, sedangkan unsur pendukung pertunjukan meliputi: tata pakaian, set properti, tata musik, dan tata pentas/set dekorasi. Namun dalam pembahasan jurnal ini lebih membahas unsur pendukung pertunjukannya.

Berdasarkan fenomena yang dikemukakan, maka yang menjadi rumusan masalah dalam jurnal penelitian ini, yaitu: Bgaimanakah Penataan Artistik Pertunjukan Teater Dul Muluk Tunas Harapan di Palembang?

\section{A. Metode Penelitian}

Penelitian ini merupakan penelitian deskrptif kualitatif dengan teknik pengumpulan data: observasi, wawancara dan dokumentasi. Difokuskan pada penataan artistik pertunjukan teater Dul Muluk dengan mengamati langsung pada pertunjukannya. Konsep yang digunakan untuk menganalisis permasalahan dalam penulisan jurnal ini adalah penataan artistik berupa: unsur pokok dan unsur pendukung pertunjukan. Unsur pokok terdiri dari: sutradara, naskah, pemain (aktor/aktris) dan penonton, sedangkan unsur pendukung pertunjukan meliputi: tata pakaian, set properti, tata musik, dan tata pentas/set dekorasi.

Teknik pengumpulan data dilakukan dengan cara observasi, wawancara dan dokumentasi, meliputi:

1. Observasi dilaksanakan untuk mengetahui unsur pokok dan pendukung pertunjukan, diamati secara langsung dan sistematis. Data yang didapatkan berupa catatan, video, foto dan lainnya.

2. Wawancara dilaksanakan kepada kelompok seni teater tradisional Dul Muluk Tunas Harapan di Palembang yaitu Bapak Elyas sebagai Pimpinan sekaligus Sutradara dari pertunjukan teater Dul Muluk yang dipentaskan di Panggung Apresiasi Belakang Museum Palembang yang diselenggarakan oleh Dinas Kebudayaan Palembang. Wawancara dilaksanakan terkait dengan unsur pokok dan pendukung pertunjukan teater.

3. Dokumentasi dilakukan pada saat pertunjukan berlangsung, serta catatan lapangan lainnya dan halhal yang mengenai unsur pokok dan pendukung pertunjukan teater Dul Muluk kelompok seni Tunas Harapan.

\section{Pembahasan}

\section{A. Tata Pakaian}

"Segala sandangan dan perlengkapannya (accessories) yang dikenakan di dalam pentas merupakan tata pakaian pentas" (Harymawan, 1993:127). Sebuah produksi teater yang dipentaskan baik dalam panggung proscenium, arena, atau dalam bentuk lain manapun adalah sesuatu hal yang dilihat dan didengar oleh penonton. Oleh sebab itu, seorang pelaku harus memperhatikan bagaimana membaca teksnya, dan harus juga memperhatikan bagaimana penampilannya. Seorang pelaku sebelum didengar suaranya, sering harus dilihat lebih dahulu. Maka dari itu, kesan yang ditimbulkan kepada penonton mengenai dirinya bergantung pada tampaknya itu. Busana yang pertama kali tampak membantu menggariskan karakter dan busanannya yang tampak kemudian memperkuat kesan itu atau mengubahnya menurut keperluan lakon.

Tata busana dalam pementasan Teater Dul Muluk sangat berperan penting guna membangun atau mempertegas karakter sesuai dengan keperluan lakon. Tata busana dalam penampilan teater sangat berperan penting karena ia turut menentukan perwatakan para pemainnya. Pada pementasan Teater Dul Muluk terdapat berbagai perwatakan yang sesuai dengan tuntunan lakon, 
karena itu sejak lama telah ditentukan bentuk dan tata warna busana para pemain. Dalam pementasan Teater Dul Muluk kostum akan lebih efektif apabila direncanakan bersama-sama dengan fase-fase produksi yang lain. Menurut Harymawan "kostum-kostum haruslah sesuai dengan scenery" (1993:130). Keselarasaan warna kostum dengan setting haruslah masuk perhitungan karena setting menjadikan latar belakang untuk kostum. Jubah beledu hitam dapat lenyap sama sekali ke dalam suatu set kain-kain yang hitam, dan dari pelaku yang kelihatan hanya muka dan tangan yang bergerak-gerak. Jika kekeliruan ini belum diperbaiki dalam latihan yang pertama dengan kostum, maka sudah terlambat untuk mengubahnya. Hal itu dapat ditolong dengan membuat plisiran emas pada semua pinggiran kostum, dengan demikian bentuk si pelaku dapat dibedakan dari setting.

Fungsi kostum menurut Harymawan adalah sebagai berikut.

"Membantu menghidupkan perwatakan pelaku; dapat menunjukkan hubungan psikologisnya dengan karakterkarakter yang lain. Individualisasi peranan; warna dan gaya kostum dapat membedakan seorang peranan dari peranan yang lain dan dari setting serta latar belakang. Memberi fasilitas dan membantu gerak pelaku; kostum tidak hanya harus menjadi bantu bagi pelaku, tetapi juga harus menambah efek visual gerak, menambah indah dan menyenangkan setiap posisi yang diambil pelaku setiap saat" (1993:131).

Dari pendapat yang telah dikemukakan, bahwa kostum menjadi hal yang penting dalam kesuksesan penampilan Teater Dul Muluk. Karena dapat membantu menunjukkan sifat psikologisnya, dengan karakter yang lain, karena kostum juga ikut membangun karakter tokoh, memberikan keindahan dari tiap-tiap pelaku/pelakon hingga terbentuk cirri khas, karakteristik dan mendapat pengalaman yang estetis.

1. Sultan Abdul Muluk Jauhari

Tokoh Sultan Abdul Muluk Jauhari merupakan Sultan dari Negeri Kehayat Berbari. Tata busana yang digunakan adalah jubah putih biru, celana warna merah, dan menggunakan tanjak, warna merah yang melambangkan keberanian, kewibawaan, kebijaksanaan, dan keperkasaan pada tokoh Sultan Abdul Muluk Jauhari.

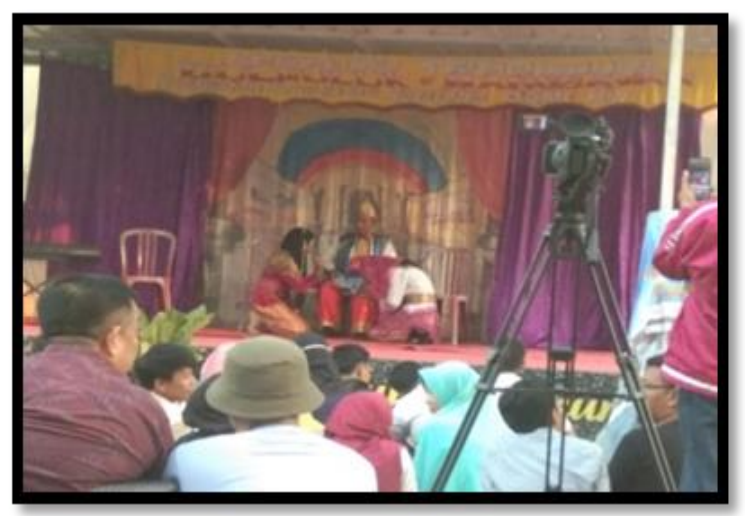

Gambar 1. Tata pakaian Sultan Abdul Muluk Jauhari. (Foto Nugroho, September 2019)
2. Permaisuri (Siti Rohma)

Tokoh permaisuri atau biasa disebut Siti Rohma istri pertama Sultan Abdul Muluk Jauhari, menggunakan kostum adat palembang baju berwarna merah dan kain songket sertra menggunakan aksesoris kalung dan gelang berwarna emas. Biasanya tokoh permaisuri diperankan oleh seorang laki-laki.

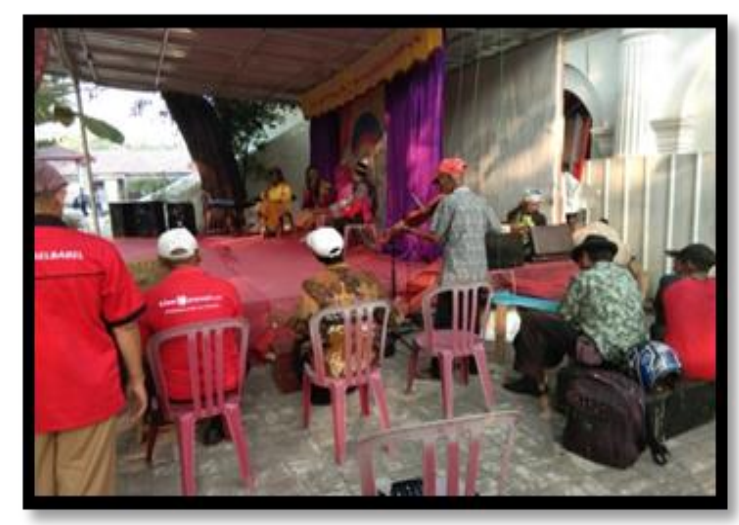

Gambar 2. Tata pakaian Sultan Abdul Muluk Jauhari. (Foto Nugroho, September 2019)

\section{Khadam}

Tokoh khadam merupakan pengikut setia Sultan Abdul Muluk Jauhari yang menggunakan kostum baju lengan panjang berwarna merah biru tidak menggunakan hiasan atau natural lebih dipertegas rias wajah, dan karakternya humor atau lawakan.

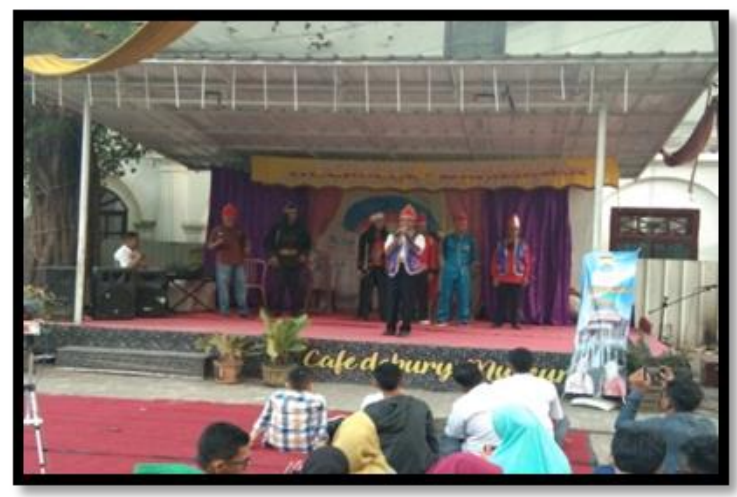

Gambar 3. Tata pakaian tokoh Khadam. (Foto Nugroho, September 2019)

\section{Makdayang}

Makdayang merupakan peran perempuan yang diperankan oleh laki-laki dan memiliki sifat seperti keibuan yang merawat dan mengasuh Permaisuri atau orang kepercayaan Permaisuri, Makdayang juga menjadi kekuatan Komedian dalam kisah Abdul Muluk Jauhari versi Tunas Harapan, dengan kostum baju kebayak kuning, dan kain berwarna coklat tanpa aksesoris atau natural, lebih dipertegas rias wajah. 


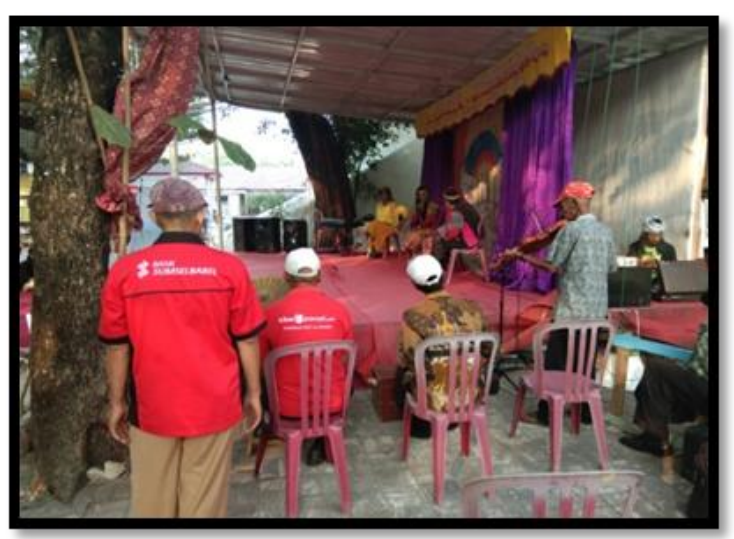

Gambar 4. Tata pakaian Makdayang.

(Foto Nugroho, September 2019)

\section{Raja Hindustan}

Raja Hindustan peran yang berwatak antagonis sebagai lawan dari tokoh Abdul Muluk yang berwajah menakutkan. Raja Hindustan dalam Teater Dul Muluk Kelompok Seni Tunas Harapan, menggunakan pakaian jubah lengan panjang berwarna hitam, serta celana panjang warna hitam dan memakai ikat kepala seperti sorban. Dalam kisah Abdul Muluk Jauhari, Raja Hindustan mengenakan properti kuda.

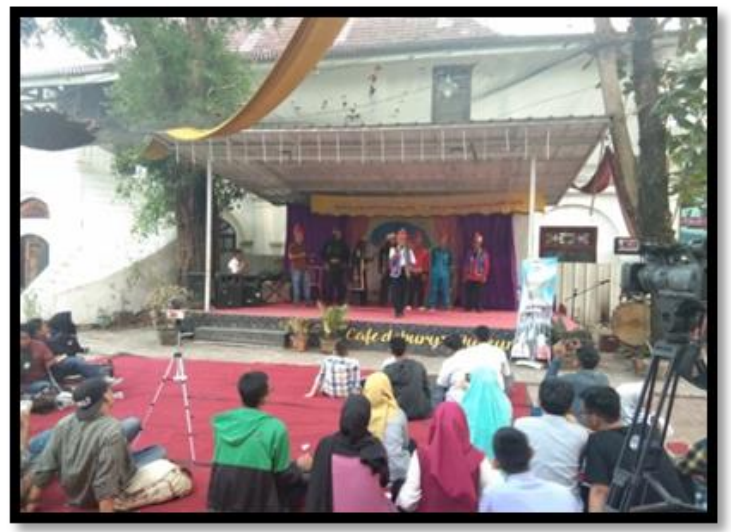

Gambar 5. Tata pakaian Raja Hindustan. (Foto Nugroho, September 2019)

\section{B. Properti}

Properti merupakan hal penting yang merupakan unsur pendukung perlengkapan dalam pertunjukan teater. Seperti halnya dalam Teater Dul Muluk properti telah ada dan digunakan sejak lama dari Teater Dul Muluk mulai diperagakan. Properti yang sangat khas dalam Teater Dul Muluk adalah kuda-kudaan yang dipergunakan pada adegan perang antara Sultan Abdul Muluk dan Sultan Syabuddin Hindi yang dalam lakonya sering disebut perang kuda. Dalam perang kuda dipergunakan dua ekor kuda yaitu kuda putih yang dikenakan oleh Sultan Abdul Muluk dan kuda hitam yang dikenakan oleh Sultan Syabuddin Hindi (Dalyono dan Saleh, 1996:128).

Properti kuda-kudaan dalam Teater Dul Muluk telah dipergunakan sejak lama. Sepanjang pengamatan properti kuda dalam penampilannya selalu dipergunakan. Bahan yang dipergunakan dalam membuat peroperti kuda ini yaitu; bambu, rotan, kain, cat dan sabut kelapa. Bambu yang dipergunakan untuk membuat kerangka (tulang), rotan dipergunakan sebagai bahan pengikat dalam membentuk kerangka, kain dipergunakan untuk membalut kerangka, cat dipergunakan untuk memberi warna dan melukis bagian kepala kuda, sedangkan sabut kelapa dipergunakan untuk membuat rambut dan ekor kuda. Wujud dari properti ini dibuat menyerupai kuda dengan ukuran yang sebenarnya.

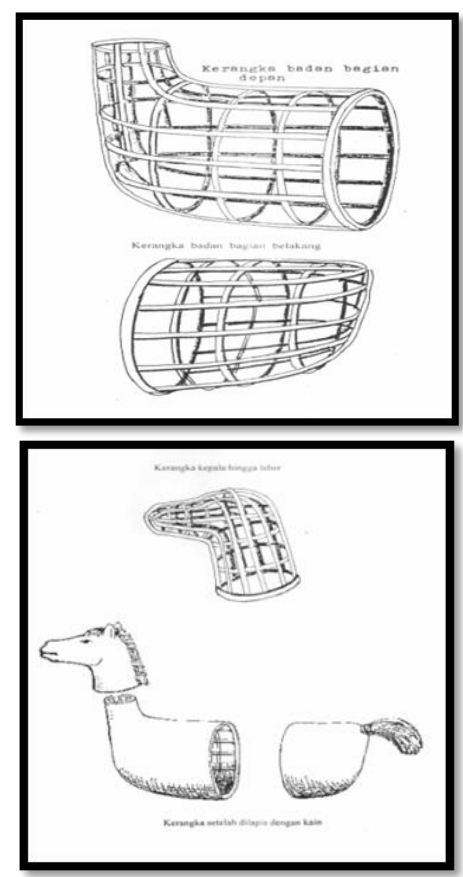

Gambar 6. Kerangka kuda bagian depan dan bagian belakang.

(Dalyono dan Saleh, 1996)

\section{Tata Musik}

Seni teater merupakan seni kolektif, begitu juga dengan Teater Dul Muluk yang didukung oleh berbagai seni lainnya seperti seni peran, seni sastra, seni rupa, seni tari, dan seni musik. "Drama di samping sebagai seni pertunjukan visual (dilihat), juga merupakan seni pertunjukan auditif (didengar). Dengan begitu, pementasan drama merupakan perpaduan antara seni pertunjukan pandang dan dengar. Oleh sebab itu, hal-hal yang mesti dipersiapkan bukan hanya segala sesuatu yang dapat dilihat, atau sesuatu yang harus diperhatikan; tetapi juga tentang sesuatu yang dapat didengar atau sesuatu yang harus diperdengarkan" (Hasannudin, 1996:159-160).

"Musik mempunyai peranan penting dalam teater. Dengan diperdengarkannya musik, penonton akan bertambah daya dan pengaruh imajinasinya. Musik yang baik dan tepat bisa membantu aktor membawakan warna dan emosi peranannya dalam adegan. Sutradara hendaklah memilih momen-momen ketika justru musik itu ditiadakan, karena dalam sementara naskah dramatik ada jenis adegan yang justru harus sepi dari segala macam efek dan bunyi" (Harymawan, 1993:162).

"Musik juga dapat dipakai sebagai awal dan penutup adegan, sebagai jembatan antara adegan satu ke adegan 
berikutnya. Dalam mempergunakan musik ini hendaklah kita berpedoman untuk memilih satu jenis tema musik saja. Jika pada permulaan memakai musik daerah, gunakan musik daerah untuk seluruh lakon, jangan dicampur musik barat atau asing lainya. Cara lain menyusun musik ialah dengan merangkai "variasi dalam kesatuan" yaitu merangkaikan dengan berbagai musik atau lagu dengan kesamaan gaya dan memperhitungkan asal musiknya sehingga hasil rangkaian itu tidak sedemikian menyolok pergantiannya demikian menurut" (Harymawan, 1993:162).

Musik merupakan bagian yang tak terpisahkan dari suatu pertunjukan Teater Dul Muluk, selain sebagai pengiring, ilustrasi, baik sebagai pembuka seluruh lakon, pembuka adegan, memberi efek pada lakon, maupun sebagai penutup lakon juga untuk memberi warna dan kesan pada adegan yang digambarkan di atas pentas.

Musik pengiring Teater Dul Muluk pada mulanya hanya terdiri dari biola, gong, jidor (beduk), gendang panjang dan akordeon. Namun seiring perkembangannya seperangkat alat musik dalam Teater Dul Muluk sudah mengalami penambahan instrument musik seperti; gitar, bass keyboard, dan drum.

Musik pengiring dalam Teater Dul Muluk berfungsi sebagai berikut:

1. Musik awal sebelum seluruh acara dimulai, terlebih dahulu diadakan tembang kisoh (bekisoh) dengan iringan musik.

2. Musik bermas pembukaan, untuk menghormati para penonton dan tuan rumah.

3. Musik ekstra, yaitu musik yang mengiringi Hadam (lawakan).

4. Musik selingan, yaitu musik sebelum pertunjukan dimulai, dan musiK diantara perindah adegan demi adegan.

5. Musik tari, yaitu musik pengiring tari dalam lakon cerita (bukan selingan).

6. Musik bermas penutup, sebagai pengiring para pemain menyanyikan lagu bermas pada akhir pertunjukan.

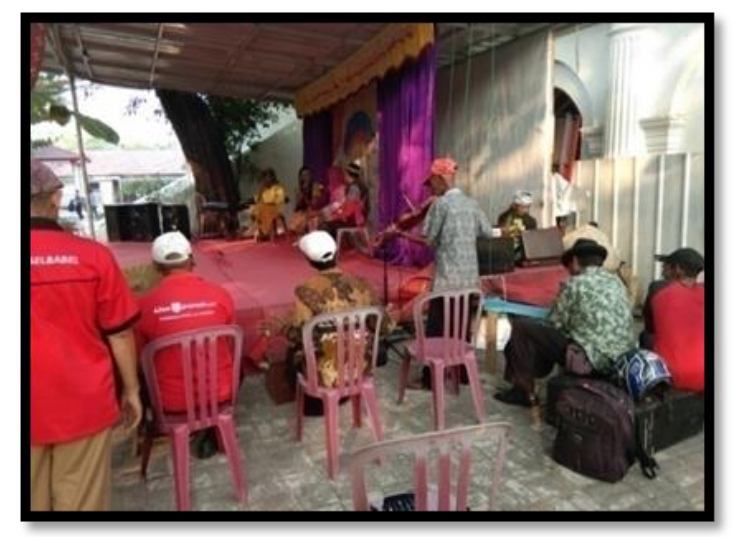

Gambar 7. Para pemain musik Teater Dul Muluk. (Foto Nugroho, September 2019)

\section{Tata Pentas}

Bentuk pentas bagi pertunjukan drama bermacammacam jenisnya. Menurut sejarah perkembangan pementasan drama itu amat beragam. Namun begitu umumnya, jenis pertunjukan drama atau teater tradisional menggunakan pentas arena terbuka dari segala sisi (Hasanuddin, 1996:147). Pentas adalah suasana tempat di mana jiwa manusia dapat terbang dengan bebas. Suatu tempat di mana seni diberi nafas, yaitu kehidupan yang mengasyikan. Sebagai karya pentas, drama memuat aneka seni, seperti tari, sastra, musik, dan peran. Masing-masing saling mendukung, tidak dapat terpisahkan.

Jika diurut posisi pemain di atas pentas, dari yang berdaya saran rendah sampai kepada yang terkuat adalah sebagai berikut :

1."Posisi terlemah adalah posisi berbaring (tidur) di atas lantai, 2. Posisi duduk di lantai pentas lebih kuat dibanding berbaring, 3. Posisi duduk di kursi lebih kuat dibanding posisi pertama dan kedua, 4. Posisi duduk di lengan-lengan kursi lebih kuat dibanding posisi pertama, kedua, dan ketiga, 5. Posisi berdiri di lantai pentas lebih kuat dibanding posisi-posisi sebelumnya, 6. Posisi berdiri di ketinggian merupakan posisi terkuat dari keseluruhan posisi pemain di atas pentas" (Hasanuddin, 1996:151).

Dengan menyadari kekuatan di atas masing-masing pemain dapat memanfaatkan untuk kegunaan aktingnya. Tata pentas dalam pertunjukan Teater Dul Muluk disesuaikan dengan acara yang dilaksanakan. Pertunjukan Teater Dul Muluk disajikan di atas panggung, di dalam ruangan, maupun di luar ruangan seperti di tanah lapang. Jadi penataan pentas pada Teater Dul Muluk tidak ada ketentuan yang mendasar sesuai kebutuhan.

Menurut Bapak Ilyas Selaku Ketua Kelompok Seni Teater Tradisional Tunas Harapan pentas Dul Muluk yang digunakan biasanya disesuaikan dengan tempat atau even yang diadakan, seperti even dalam acara yang difasilitasi oleh pemerintah menggunakan panggung modern, dengan tata lighting yang memadai, tetapi sebaliknya jika Teater Dul Muluk tampil pada acara pernikahan, khitanan, dan lain sebagainya biasanya menggunakan tabir atau layar sebagai latar belakang yang berfungsi sebagai penegas suasana tempat kejadian dengan lighting seadanya (Ilyas, wawancara, September 2019).

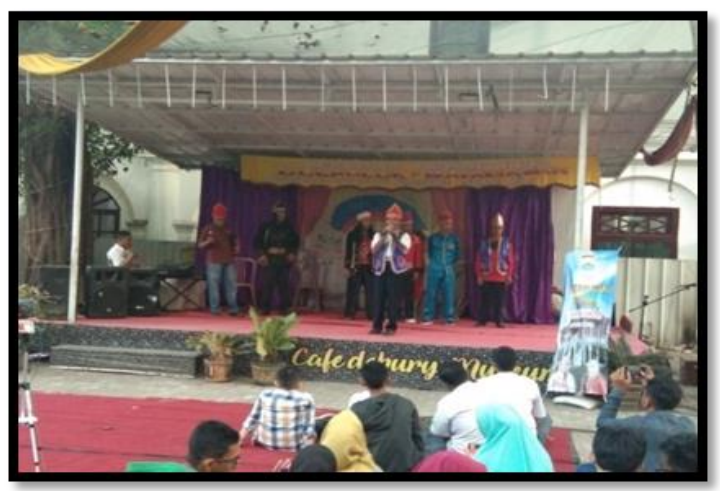

Gambar 8. Panggung Pertunjukan Teater Dul Muluk penyelenggara di Disbud Kota Palembang.

(Foto Nugroho, September 2019) 


\section{Kesimpulan}

Melalui pendekatan teori daramaturgi dalam penulisan jurnal ini. Penulis menganalisi unsur-unsur pertunjukan berdasarkan:

1. Tata Pakaian: tata pakaian dalam pementasan Teater Dul Muluk sangat berperan penting guna membangun atau mempertegas karakter sesuai dengan keperluan lakon. Pada pementasan Teater Dul Muluk terdapat berbagai perwatakan yang sesuai dengan tuntunan lakon, karena itu sejak lama telah ditentukan bentuk dan tata warna pakaian para pemain. Dalam pementasan Teater Dul Muluk kostum akan lebih efektif apabila direncanakan bersama-sama dengan fase-fase produksi yang lain. Jubah beledu hitam dapat lenyap sama sekali ke dalam suatu set kain-kain yang hitam, dan dari pelaku yang kelihatan hanya muka dan tangan yang bergerak-gerak. Jika kekeliruan ini belum diperbaiki dalam latihan yang pertama dengan kostum, maka sudah terlambat untuk mengubahnya. Hal itu dapat ditolong dengan membuat plisiran emas pada semua pinggiran kostum, dengan demikian bentuk si pelaku dapat dibedakan dari setting,

2. Properti: Properti kuda-kudaan dalam Teater Dul Muluk telah dipergunakan sejak lama. Sepanjang pengamatan properti kuda dalam penampilannya selalu dipergunakan. Bahan yang dipergunakan dalam membuat peroperti kuda ini yaitu; bambu, rotan, kain, cat dan sabut kelapa. Bambu dipergunakan untuk membuat kerangka (tulang), rotan dipergunakan sebagai bahan pengikat dalam membentuk kerangka, kain dipergunakan untuk membalut kerangka, cat dipergunakan untuk memberi warna dan melukis bagian kepala kuda, sedangkan sabut kelapa dipergunakan untuk membuat rambut dan ekor kuda. Wujud dari properti ini dibuat menyerupai kuda dengan ukuran yang sebenarnya,

3. Tata Musik: Musik merupakan bagian yang tak terpisahkan dari suatu pertunjukan Teater Dul Muluk, selain sebagai pengiring, ilustrasi, baik sebagai pembuka seluruh lakon, pembuka adegan, memberi efek pada lakon, maupun sebagai penutup lakon juga untuk memberi warna dan kesan pada adegan yang digambarkan di atas pentas. Musik pengiring Teater Dul Muluk pada mulanya hanya terdiri dari biola, gong, jidor (beduk), gendang panjang dan akordeon. Namun seiring perkembangannya seperangkat alat musik dalam Teater Dul Muluk sudah mengalami penambahan instrument musik seperti; gitar, bass keyboard, dan drum,

4. Tata Pentas: Tata pentas dalam pertunjukan Teater Dul Muluk disesuaikan dengan acara yang dilaksanakan. Pertunjukan Teater Dul Muluk disajikan di atas panggung, di dalam ruangan, maupun di luar ruangan seperti di tanah lapang. Jadi penataan pentas pada Teater Dul Muluk tidak ada ketentuan yang mendasar sesuai kebutuhan. Menurut Bapak Ilyas Selaku Ketua Kelompok Seni Teater Tradisional Tunas Harapan pentas Dul Muluk yang digunakan biasanya disesuaikan dengan tempat atau even yang diadakan, seperti even dalam acara yang difasilitasi oleh pemerintah menggunakan panggung modern, dengan tata lighting yang memadai, tetapi sebaliknya jika Teater Dul Muluk tampil pada acara pernikahan, khitanan, dan lain sebagainya biasanya menggunakan tabir atau layar sebagai latar belakang yang berfungsi sebagai penegas suasana tempat kejadian dengan lighting seadanya (Ilyas, wawancara, September 2019).

\section{Daftar Pustaka}

Bandem, I Made dan Sal Murgiyanto. 1996. Teater Daerah Indonesia. Yogyakarta: Kanisius.

Dony, NNA. 2018. Dramatik Plot Teater Dulmuluk Naskah Lakon Zahara Siti. Palembang: Jurnal Seni Desain dan Budaya.

Harymawan, RMA. 1993. Dramaturgi. Bandung: PT Rosdakarya.

Hasanuddin, WS. 1996. Drama Karya dalam Dua Dimensi (Kajian Teori, Sejarah, dan Analisis). Bandung: Angkasa.

Salleh, Abdullah dan R. Dalyono. 1996. Kesenian Teater Tradisional Palembang Teater Dulmuluk. Proyek Pembinaan dan Pengembangan Kesenian Tradisional Palembang. 